Cornell Law Library

Scholarship@Cornell Law: A Digital Repository

Cornell Law Faculty Publications

3-15-2005

\title{
On-line Consumer Standard-Form Contracting Practices: A Survey and Discussion of Legal Implications
}

Robert A. Hillman

Cornell Law School, rah16@cornell.edu

Follow this and additional works at: http://scholarship.law.cornell.edu/lsrp_papers

Part of the Contracts Commons

\section{Recommended Citation}

Hillman, Robert A. , "On-line Consumer Standard-Form Contracting Practices: A Survey and Discussion of Legal Implications" (2005). Cornell Law Faculty Publications. Paper 29.

http://scholarship.law.cornell.edu/lsrp_papers/29

This Article is brought to you for free and open access by Scholarship@Cornell Law: A Digital Repository. It has been accepted for inclusion in Cornell Law Faculty Publications by an authorized administrator of Scholarship@Cornell Law: A Digital Repository. For more information, please contact jmp8@cornell.edu. 


\title{
CORNELL LAW SCHOOL
}

\section{Legal StUdies ReseARCH PAPER SERIES}

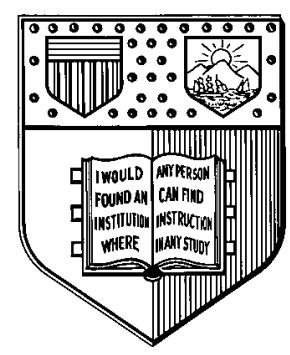

\section{On-line Consumer Standard-Form Contracting Practices: A Survey and Discussion of Legal Implications}

\section{Robert A. Hillman}

\author{
Cornell Law School \\ Myron Taylor Hall \\ Ithaca, NY 14853-4901
}

Cornell Law School research paper No. 05-012

This paper can be downloaded without charge from:

The Social Science Research Network Electronic Paper Collection:

$\underline{\text { http://ssrn.com/abstract }=686817}$ 


\title{
ON-LINE CONSUMER STANDARD- FORM CONTRACTING PRACTICES: A SURVEY AND DISCUSSION OF LEGAL IMPLICATIONS
}

Draft 3/23

\author{
Robert A. Hillman*
}

In a recent article, Jeffery Rachlinski and I analyzed whether contract law's approach to the problem of paper standard forms can effectively govern electronic forms. ${ }^{1}$ Some analysts believe that contract law must evolve to police business's new Internet strategies for taking advantage of consumers. Conversely, others assert that contract law must create a new framework to facilitate business's use of the new technology. Relying on our assumptions about how e-businesses use the Internet and how consumers treat their e-standard forms, we concluded that Internet contracting is not fundamentally different from the paper world. Accordingly, major changes in the approach of contract law are not imperative. ${ }^{2}$

This paper tests the assumptions we made about consumer behavior when agreeing to estandard forms by offering some empirical evidence of consumer practices. Part I revisits our assumptions about these practices. To test these assumptions, Part II reports on a survey of 92 contracts students' e-standard form practices. The survey inquired about all aspects of their practices, including frequency of contracting, the place and time of such contracting, whether they read their e-forms, the reasons for reading or failing to read, and the factors that would promote reading.

To the extent that first-year law-student respondents accurately reflect the e-contracting practices of Internet users, ${ }^{3}$ the survey substantiates the assertions made in our earlier article, while refining our understanding of Internet standard-form contracting. Although the survey

* Edwin H. Woodruff Professor of Law, Cornell Law School. I prepared this manuscript for a conference, "Is Consumer Protection an Anachronism in the Information Economy," at the University of Washington School of Law. Thanks to Sid DeLong, Ted Eisenberg, Darian Ibrahim, and Jeff Rachlinski for helpful comments. Thanks also to Conray Tseng, Cornell class of 06, for able research assistance. Conray also wrote the first draft of the survey discussed in this article.

1 Robert A. Hillman \& Jeffrey J. Rachlinski, Standard-Form Contracting in the Electronic Age, 77 N.Y.U. L. Rev. 429 (2002).

${ }^{2}$ On all of this, see id.

3 See infra notes, and accompanying text for a discussion of this issue. 
reinforces our assumption that people generally do not read their e-standard forms, ${ }^{4}$ the truth is a bit more complicated. Few respondents read their e-standard forms beyond price and description of the goods or services "as a general matter." 5 Further, beyond price and description, a large minority of respondents do not read their forms at all. However, more than a third of the respondents read their forms when the value of the contract is high and more than a third read when the vendor is unknown. ${ }^{6}$ Further, a small cadre of respondents read particular terms beyond price and description, primarily warranties and product information warnings. ${ }^{7}$

The survey also illustrates that impatience accounts most often for the failure of respondents to read their forms. ${ }^{8}$ Not surprisingly, therefore, the survey also reveals that respondents rarely shop for advantageous terms, despite their greater availability on the Internet. ${ }^{9}$

In light of these and other findings, Part III continues the discussion in our earlier paper of contract law's appropriate response to e-standard forms. Part III focuses on those situations where reading presently is least likely, namely transactions between consumers and well-known on-line or brick and mortar vendors for unexceptionally priced goods. Standard forms are not a problem and third-party regulation is not necessary, of course, if, notwithstanding consumer failure to read and shop in this context, market pressures or other motivations cause businesses to draft fair, reasonable terms. However, Part III first briefly revisits the reasons Rachlinski and I believe that contract law must be wary of business overreaching in the e-environment. It then turns to possible solutions to the problem of overreaching, paying particular attention to the survey results.

\section{Assumptions About Consumer On-Line Standard-Form Contracting}

In our earlier work, Professor Rachlinski and I posited that e-consumers can better fend for themselves than those agreeing to standard forms in the paper world:

Several factors suggest that consumers can defend themselves against undesirable terms more easily in the electronic environment. E-consumers can shop in the privacy of their own homes, where they can make careful decisions with fewer time constraints. They can leave their computers and return before

${ }^{4}$ See infra notes, and accompanying text.

${ }^{5}$ See infra notes, and accompanying text.

${ }^{6}$ On all of this, see infra notes , and accompanying text.

7 See infra notes, and accompanying text.

${ }^{8}$ See infra notes , and accompanying text.

${ }^{9}$ See infra notes, and accompanying text. 
completing their transactions, giving them time to think and investigate further. Also, at present, e-consumers tend to be better educated and wealthier than paperworld consumers, suggesting that they can better fend for themselves in the marketplace.

The Internet has also taken comparison shopping to a level that is unimaginable in the real world. The ease with which consumers can compare business practices, including the content of standard forms, suggests that consumers do not need judicial intervention to protect themselves from business abuse. $^{10}$

Notwithstanding these benefits of Internet contracting, we noted several factors in the eworld that undermine these benefits, which we categorized as either rational, cognitive, or social reasons for the failure to read e-terms. The rational factors overlap explanations from the paper world about why people do not read their forms, such as the impenetrability of most boilerplate, the ability of e-businesses to present the forms in a manner that deters reading, consumers' lack of bargaining power (indeed the lack of anyone with whom to bargain), the lack of diversity of terms within an industry, and the knowledge that boilerplate generally allocates the risks of remote contingencies. ${ }^{11}$ In short, an e-reader may weigh the costs and benefits of reading and not reading and rationally find a net benefit in not reading.

Cognitive factors for failing to read are irrational, but prominent, both in the paper and electronic worlds. They include consumers' propensity to underestimate the likelihood of adverse events and their tendency to rely on intuition and hunches instead of processing all of the information. ${ }^{12}$

At first blush, social factors that affect how consumers treat standard forms would seem to be very different and favorable to e-consumers reading more:

The electronic medium ameliorates the social factors that support judicial scrutiny of standard-form contracting in the paper world. Indeed, perhaps the most obvious difference between electronic and paper contracting is that, in the paper world, sales people usually deal with consumers face to face, whereas electronic consumers transact business from the privacy of their home or office. All of the social factors that deter consumers from reading standard terms depend upon the influence of a live social situation that electronic contracting lacks. E-

\footnotetext{
${ }^{10}$ Hillman \& Rachlinski, supra note , at 478-79 .

${ }^{11}$ Id. at 480.

${ }^{12}$ Id. at $483-84$.
} 
businesses cannot easily duplicate the effects of an endearing, but manipulative, agent in the electronic format. To the extent that the courts worry that businesses use their agents to manipulate consumers into signing contracts precipitously, then reliance on electronic contracting alleviates these concerns. ${ }^{13}$

Despite these potential advantages for consumers, we pointed out the likelihood that econsumers would not assign the same significance to a mouse click as a signature on a paper form. As we suggested, "the requirement of a signature is nothing less than the law's signal to consumers that the document in front of them is important and that they should be cautious about

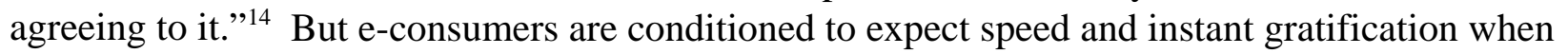
using their computers, including when they engage in Internet contracting. Put differently, consumers may be overeager, even "click-happy" and may therefore fail to research their estandard contracts. ${ }^{15}$

We predicted that, combined with the rational and cognitive factors for not reading, consumer impatience and failure to appreciate the significance of clicking meant that consumers would not utilize their extra time and the absence of distractions, but would resemble their paperworld counterparts who fail in large part to comprehend, investigate, or compare standard forms. Nevertheless, we cautioned that "[c]ourts should . . . remain attuned to emerging empirical evidence and change their degree of deference [to standard forms] as necessary."16 Part II consists of a modest first step to accumulate some information on what consumers are actually doing when they enter e-standard form contracts.

\section{Survey}

A. Introduction. To test many of the assumptions discussed in Part I about consumer estandard form contracting behavior, I administered a survey to my first-year class of 92 contracts students. Needless to say, although Internet users are generally "younger, wealthier, and better educated than conventional consumers," ${ }^{\prime 17}$ I cannot claim that the sample mirrors the general population of e-consumers. Still, careful reading may be the most important skill law schools try to teach and this study shows that first-year law students generally do not read their standard
13 Id. at 480 .
${ }^{14}$ Id. at 481.
15 Id. at 480. I look more closely at e-clicking behavior and impulse shopping in Robert A. Hillman, Internet Standard-Form Contracting-Would Website Disclosure of E-Terms Backfire? (draft).
${ }^{16}$ Id. at 485.
17 Id. at 467. 
forms or shop for terms. It is therefore likely that the general population of internet users are even less likely to read and shop. In addition, I administered the questionnaire before we covered formation issues and standard forms, so that respondents' views might better represent the general population of Internet users. ${ }^{18}$

As already noted, the survey, reproduced in full in the appendix, inquired, among other things, about the frequency of on-line contracting, the place and time of making such contracts, whether and to what degree respondents read their forms, which terms they were more likely to read, the reasons they failed to read, and factors that would promote reading. I inquired both with respect to on-line purchases of goods and services ${ }^{19}$ and subscriptions such as a news or virus protection services. I also compared the practices of men and women and of frequent and occasional users.

As we shall see, for the most part, the survey results support the assumptions discussed in Part I, while refining our understanding of contracting practices.

B. Results. Although the survey inquired about both on-line purchases of goods and services and on-line subscriptions, and compared the practices of men and women and of frequent (once a month or more) and occasional (once every six months or less) users, the following discussion focuses on the results of the entire sample's purchase of on-line goods and services. I report results comparing men and women, frequent or occasional users, and subscription contractors only when the differences in these results may be noteworthy.

1. Frequency of purchases and subscriptions. Table $1 \mathrm{~A}$ shows that respondents are not regularly purchasing or subscribing over the Internet. ${ }^{20}$ Only 3\% of the respondents answering this question make purchases every week (3/90). ${ }^{21}$ The highest percentage purchase only once a month (40\% or $36 / 90)$. Sixty-nine percent purchase either once a month or every two to three months.

${ }^{18}$ I intend to administer the questionnaire to additional groups.

${ }^{19}$ On-line services include, for example, sites dealing with on-line database searches, auctions, product search engines, and banking, dating, and phone services.

20 On the other hand, Internet sales are growing. In 2002, for example, business to consumer sales totaled $\$ 76$ billion, which was roughly $3 \%$ of all retail sales. E-Commerce \& Internet Business Almanac 2003/2004, Ch.1, pg. 3, found at WWW.PlunkettResearch.com.

21 Two of the 92 respondents did not answer this question. Several tables that follow also reflect the failure of all 92 respondents to answer each question. 
Table 1A: Frequency of On-line Purchases

\begin{tabular}{|l|c|c|}
\hline Frequency of Purchases & $\begin{array}{c}\text { Number of } \\
\text { Responses }\end{array}$ & $\begin{array}{c}\text { \% of } \\
\text { Responses }\end{array}$ \\
\hline Every week & 3 & $3 \%$ \\
\hline Every two weeks & 17 & $19 \%$ \\
\hline Once a month & 36 & $40 \%$ \\
\hline Every two to three months & 26 & $29 \%$ \\
\hline Every six months & 5 & $6 \%$ \\
\hline Once a year & 3 & $3 \%$ \\
\hline Never & 0 & $0 \%$ \\
\hline Total & $\mathbf{9 0} *$ & $\mathbf{1 0 0} \%$ \\
\hline
\end{tabular}

* Two of the ninety-two total respondents did not indicate the frequency of their purchases.

Table 1B shows that respondents are relatively equally divided in the number of their subscriptions, ranging from none to five or more. Almost half of the respondents (48\%) subscribe to three or more services, suggesting that many respondents are active on the Internet even if they do not frequently make purchases. ${ }^{22}$

Table 1B: Number of On-line Subscriptions

\begin{tabular}{|l|c|c|}
\hline Number of Online Subscriptions & $\begin{array}{c}\text { Number of } \\
\text { Responses }\end{array}$ & $\begin{array}{c}\text { \% of } \\
\text { Responses }\end{array}$ \\
\hline None & 21 & $24 \%$ \\
\hline One to two & 25 & $28 \%$ \\
\hline Three to four & 19 & $21 \%$ \\
\hline Five or more & 24 & $27 \%$ \\
\hline Total & $\mathbf{8 9 *}$ & $\mathbf{1 0 0 \%}$ \\
\hline
\end{tabular}

* Three of the ninety-two total respondents did not indicate the number of online subscriptions.

2. Where and when respondents make on-line purchases. Tables $2 \mathrm{~A}$ and $2 \mathrm{~B}$ illustrate

${ }^{22}$ Of the $27 \%$ with five or more subscriptions, men outnumber women two to one (67\% men or $16 / 24$; $33 \%$ women or $8 / 24$ ). 
that respondents overwhelmingly make on-line purchases at home (83\% or $75 / 90)$ and, more often than not, in the evening (62\% or 55/89). The largest number contract late at night (36\% or 32/89).

Table 2A: Where Respondents Make On-line Purchases

\begin{tabular}{|l|c|c|}
\hline Location & $\begin{array}{c}\text { Number of } \\
\text { Responses }\end{array}$ & $\begin{array}{c}\text { \% of } \\
\text { Responses }\end{array}$ \\
\hline Home & 75 & $83 \%$ \\
\hline School/Work & 14 & $16 \%$ \\
\hline Cyber-Café & 0 & $0 \%$ \\
\hline Other & 1 & $1 \%$ \\
\hline Total & $\mathbf{9 0 *}$ & $\mathbf{1 0 0 \%}$ \\
\hline
\end{tabular}

* Two of the ninety-two total respondents did not indicate the location of their online purchases.

Table 2B: When Respondents Make On-line Purchases

\begin{tabular}{|l|c|c|}
\hline Time & $\begin{array}{c}\text { Number of } \\
\text { Responses }\end{array}$ & $\begin{array}{c}\text { \% of } \\
\text { Responses }\end{array}$ \\
\hline Morning & 0 & $0 \%$ \\
\hline Afternoon & 7 & $8 \%$ \\
\hline Early evening & 23 & $26 \%$ \\
\hline Late at night & 32 & $36 \%$ \\
\hline No particular time & 27 & $30 \%$ \\
\hline Total & $\mathbf{8 9 *}$ & $\mathbf{1 0 0 \%}$ \\
\hline
\end{tabular}

* Three of the ninety-two total respondents did not indicate the time of their online purchases.

3. Do respondents read their Internet standard forms? Perhaps the most important set of findings of the survey substantiates what analysts have been reporting all along about standardform contracting in general: Table 3A shows that, beyond price and product description (which terms the survey questions and this discussion assume respondents read), only $4 \%$ of the sample of Internet purchasers (4/92) read their electronic contracts "as a general matter.”

Forty-four percent (40/92) of the respondents reported affirmatively that, other than price and product description, they do not read their electronic contracts as a general matter. By 
running a cross-tabulation, I determined that four of this group of 40 non-readers nonetheless may be prompted to read depending on the term, type of vendor, or value of the item purchased. Thus, 36 respondents (39\%) are hard-core non-readers beyond price and description of goods, regardless of the circumstances. Tables 5A through $\mathrm{C}$ below, however, show that 54 respondents (including the four non-readers who may be prompted to read) or 59\% may be spurred on to read depending on the term, type of vendor, or value of the item purchased. ${ }^{23}$

Table 3A: Do Respondents Read Their E-Purchase Contract?*

\begin{tabular}{|l|c|c|}
\hline Responses & $\begin{array}{c}\text { Responses } \\
\text { Out of 92 } \\
\text { Respondents }\end{array}$ & $\begin{array}{c}\text { \% of } \\
\text { Responses }\end{array}$ \\
\hline Yes & 4 & $4 \%$ \\
\hline No & 40 & $44 \%$ \\
\hline Depends on term & 16 & $17 \%$ \\
\hline Depends on vendor & 33 & $36 \%$ \\
\hline Depends on value of item purchased & 34 & $37 \%$ \\
\hline
\end{tabular}

* Respondents could select more than one response.

Table 3B shows that a larger percentage of the entire sample, 13\% (12/92), generally read their electronic subscription contracts. This result is counterintuitive because subscription contracts are often free and should be easier to avoid, such as by cancelling AOL ${ }^{24}$ On the other hand, fifty-two percent of all of the respondents (48/92) do not read their subscription contracts as a general matter, a higher percentage than purchasers. The subscription results reinforce the conclusion that consumers generally do not read their e-standard terms.

${ }^{23}$ See infra notes, and accompanying text. The total of 90 respondents $(36+54)$ does not include two respondents who generally read their e-purchase standard forms regardless of the circumstances.

${ }^{24}$ Thanks to Frank Balotti for mentioning this. 
Table 3B: Do Respondents Read E-Subscription Contracts?*

\begin{tabular}{|l|c|c|}
\hline Response & $\begin{array}{c}\text { Number of } \\
\text { Responses } \\
\text { Out of 92 } \\
\text { Respondents }\end{array}$ & $\begin{array}{c}\text { \% of } \\
\text { Responses }\end{array}$ \\
\hline Yes & 12 & $13 \%$ \\
\hline No & 48 & $52 \%$ \\
\hline Depends on the term & 13 & $14 \%$ \\
\hline Depends on the vendor & 17 & $19 \%$ \\
\hline Depends on the service & 20 & $22 \%$ \\
\hline
\end{tabular}

* Respondents could select more than one response.

4. Reasons for failing to read e-purchase contracts. Table 4 sets forth reasons why respondents purchasing goods and services "fail to read the entire contract" and breaks down the results by frequency of purchase. The most frequent response is that they "are in a hurry" (65\% or 60/92). This predominance of hurried purchasers is consistent across the various categories of respondents (frequent or occasional purchasers, men and women, and subscribers). ${ }^{25}$ The time constraint is very likely self-imposed in light of the time and place that most respondents make their purchases, namely at night in their homes. ${ }^{26}$

Other significant reasons for failing to read track those typically mentioned by analysts of paper standard forms, namely optimism that nothing will go wrong (42\%), the lack of diversity of competitors' terms (42\%), a belief that the terms will be fair (32\%), and a belief that the law will weed out egregious terms (26\%). Only 13\% explained their failure to read based on failing to understand the "legalese," but the relative unpopularity of this reason, often set forth as a reason that people do not read paper terms, may be explained by respondents' law student training (or bravado). In short, people who are not studying law probably would elect this reason in higher numbers.

${ }^{25}$ Seventy percent of frequent purchasers and $75 \%$ of occasional purchasers explained that they were in a hurry. Seventy two percent of men and $62 \%$ of women were also in a hurry. Sixty-one percent of subscribers were in a hurry.

${ }^{26}$ See supra notes and accompanying text. 
Table 4: Reasons for Not Reading E-Purchase Contracts*

\begin{tabular}{|l|c|c|}
\hline Reason for Not Reading & $\begin{array}{c}\text { Number of Responses } \\
\text { out of 92 } \\
\text { Respondents }\end{array}$ & \% of Total Responses \\
\hline Not understand “legalese” & 12 & $13 \%$ \\
\hline Nothing will go wrong & 39 & $42 \%$ \\
\hline Terms will be fair & 30 & $33 \%$ \\
\hline In a hurry & 60 & $65 \%$ \\
\hline Competitor's terms same & 39 & $42 \%$ \\
\hline Law invalidate egregious terms & 24 & $26 \%$ \\
\hline
\end{tabular}

* Respondents could select more than one response.

5. Factors that induce respondents to read e-purchase contracts. Tables 5A through $\mathrm{C}$ focus on those $59 \%$ of the respondents (54/92) who, depending on the circumstances, may be prompted to read their e-purchase contracts beyond price and description of the goods. ${ }^{27}$ Table $5 \mathrm{~A}$ shows that $63 \%$ of these respondents (34/54) read depending on the value of the item purchased. Although I could have worded this question more felicitously to clarify that these respondents read when the value is high, a response to another question, asked of all 92 respondents, confirms this. The most frequent response (70\% or 64/92) to question 10 , concerning what would increase the likelihood that a respondent would read terms, is when the purchase was expensive. $^{28}$

27 The 54 respondents consist of 48 who did not answer yes or no to survey question 4 (indicating that they read or not solely depending on the circumstances), 4 respondents who answered no to question 4, but also answered 4c, d, e or $\mathrm{f}$ (indicating that they generally do not read, but can be spurred on to read depending on the circumstances), and 2 respondents who answered yes to question 4 (indicating that they generally read, but their reading may be influenced by the circumstances).

28 See Appendix, question 10. Unfortunately, the survey did not specify the meaning of "expensive." The survey reveals only that the more expensive the purchase, the more likely respondents read. 
Table 5A: Circumstances That Prompt Reading E-Purchase Contracts*

\begin{tabular}{|l|c|c|}
\hline Circumstance & $\begin{array}{c}\text { Responses Out of 54 } \\
\text { Who May Read }\end{array}$ & \% of Responses \\
\hline Value of contract & 34 & $63 \%$ \\
\hline Type of vendor & 33 & $61 \%$ \\
\hline Nature of term & 16 & $30 \%$ \\
\hline
\end{tabular}

* Respondents could select more than one response.

Table $5 \mathrm{~A}$ also reveals that $61 \%$ of the respondents who may be prompted to read (33/54) do so depending on the nature of the vendor. Of these 33 respondents, Table $5 \mathrm{~B}$ shows that $100 \%$ read the terms of "unknown vendors," while only $21 \%$ (7/33) read the terms of "a well known vendor."

Table 5B: Types of Vendors That Induce People to Read Their E-Purchase Contracts*

\begin{tabular}{|l|c|c|}
\hline Type of Vendor & $\begin{array}{c}\text { Responses } \\
\text { Out of 33 } \\
\text { Who May } \\
\text { Read }\end{array}$ & $\begin{array}{c}\text { \% of } \\
\text { Responses }\end{array}$ \\
\hline Previously used vendor & 2 & $6 \%$ \\
\hline Online website of an existing brick and mortar vendor & 3 & $9 \%$ \\
\hline Well known online vendor & 7 & $21 \%$ \\
\hline An unknown vendor & 33 & $100 \%$ \\
\hline
\end{tabular}

* Respondents could select more than one response.

Finally, Table 5A shows that $30 \%$ of the respondents who may be prompted to read do so because of their interest in particular terms (16/54). Table 5C reveals that ninety-four percent of these 16 respondents (15/16) are likely to read "warranties/guarantees/return policy. ${ }^{29}$ Seventyfive percent of these respondents (12/16) read "product information disclosures/warnings" as well. Choice of form/law terms and arbitration clauses drew little attention from those who read depending on the term ( $6 \%$ or $1 / 16$ each), even though these terms have been disputed in the

${ }^{29}$ But recall that this means that only 15 out of 92 respondents are likely to read warranties, guarantees, or return policies. Ironically, 73 out of 92 respondents regard these terms as important enough to convince them not to purchase if unfavorable. See Appendix, question 9. 
courts. $^{30}$

Table 5C: Terms That Induce People to Read Their E-Purchase Contracts*

\begin{tabular}{|l|c|c|}
\hline Term & $\begin{array}{c}\text { Responses } \\
\text { Out of 16 } \\
\text { Who May } \\
\text { Read }\end{array}$ & $\begin{array}{c}\text { \% of } \\
\text { Responses }\end{array}$ \\
\hline Choice of forum/law & 1 & $6 \%$ \\
\hline Arbitration clause & 1 & $6 \%$ \\
\hline Production information, disclosures and warnings & 12 & $75 \%$ \\
\hline Warranties, guarantees, or return policies & 15 & $94 \%$ \\
\hline
\end{tabular}

* Respondents could select more than one response.

In sum, Tables 3A and 5A through $\mathrm{C}$ together reveal that, beyond price and description of goods, there is a substantial, but less than majority, base of hard-core non-readers. However, more than a third of the respondents read when they purchase high-priced items and more than a third read when the vendor is unknown. Further, a small but significant number of respondents read particular terms beyond price and description.

6. Shopping for terms. Table 6A indicates that respondents who read at least some of the terms of their on-line purchases of goods and services, nevertheless do little shopping for advantageous ones. Only 7\% (5/69) shop as a general matter, while only about half (54\% or 37/69) even shop for the best price or based on the description of the goods. ${ }^{31}$ Thirty-nine per cent of the respondents (27/69) do not shop at all.

30 See Christina L. Kunz, et al., Browse-Wrap Agreements: Validity of Implied Assent in Electronic Form Agreements, 59 Bus. Lawyer 279, 280-81 (2003).

31 Twenty-three students did not respond to this question (suggesting they do not even read the price and description), whereas the discussion of Table 3A reveals that 36 respondents do not read at all, other than price and description of the goods. See supra note 23, and accompanying text. This means that 13 students read only the price and description terms. 
Table 6A: If You Generally Read Some of the Terms of Your E-Purchase Contracts, Do You Shop for Terms?

\begin{tabular}{|l|c|c|}
\hline Response & $\begin{array}{c}\text { Number of } \\
\text { Responses }\end{array}$ & $\begin{array}{c}\text { \% of Total } \\
\text { Responses }\end{array}$ \\
\hline Yes & 5 & $7 \%$ \\
\hline $\begin{array}{l}\text { Yes, but only with respect to price and/or description of the } \\
\text { item purchased }\end{array}$ & 37 & $54 \%$ \\
\hline No & 27 & $39 \%$ \\
\hline Total & 69 & $100 \%$ \\
\hline
\end{tabular}

Table 6B shows that the number who do not shop is even higher for those agreeing to subscriptions (57\%). Perhaps these respondents perceive a lack of subscription competitors and therefore little likelihood of finding more favorable terms by shopping.

Table 6B: If you Generally Read Some of the Terms of Your E-Subscription Contracts, Do You Shop for Terms?

\begin{tabular}{|l|c|c|}
\hline Response & $\begin{array}{l}\text { Number of } \\
\text { Responses }\end{array}$ & $\begin{array}{c}\text { \% of Total } \\
\text { Responses }\end{array}$ \\
\hline Yes & 5 & $8 \%$ \\
\hline $\begin{array}{l}\text { Yes, but only with respect to price and/or } \\
\text { description of the service. }\end{array}$ & 23 & $35 \%$ \\
\hline No & 38 & $57 \%$ \\
\hline Total & 66 & $100 \%$ \\
\hline
\end{tabular}

7. Formation processes that induce reading on-line purchase contracts. Table 7 presents a menu of processes for forming e-purchase contracts and reports the likelihood of each inducing respondents to read the terms. The most frequent response was that respondents would read if they were required to click "I agree" at the end of each term (49\% or 45/92). ${ }^{32}$ Interestingly, more respondents thought that they would read bold or otherwise highlighted text (42\% or 39/92) than either when the terms appear in a pop-up window (24\% or 22/92) or when the terms appear on the screen as a series of individual windows that must be clicked (23\% or 21/92). Merely

32 Forty-two percent (39/92) of the respondents are more likely to read their subscription terms when they have to click at the end of each term. See Appendix, survey question 10. This was the highest response rate as well. 
clicking "I agree" at the end of all of the terms would induce reading only among $17 \%$ of the respondents (16/92).

Perhaps the most significant finding revealed by Table 7, but not surprising, is that only $5 \%(5 / 92)$ of the respondents are more likely to read when they "must click" on a link to another page to read the terms. This "browse wrap" strategy, however, is heavily utilized by on-line merchants. $^{33}$

Table 7: Formation Processes That Induce Reading the E-Purchase Contract*

\begin{tabular}{|c|c|c|}
\hline Term & $\begin{array}{l}\text { Number of Responses } \\
\text { Out of } 92 \text { Respondents }\end{array}$ & \% of Total Responses \\
\hline $\begin{array}{l}\text { Click on a link to another page } \\
\text { to read terms }\end{array}$ & 5 & $5 \%$ \\
\hline $\begin{array}{l}\text { Terms appear in a pop-up } \\
\text { window }\end{array}$ & 22 & $24 \%$ \\
\hline $\begin{array}{l}\text { Terms appear on the screen in } \\
\text { bold or highlighted text }\end{array}$ & 39 & $42 \%$ \\
\hline $\begin{array}{l}\text { Terms appear on screen in a } \\
\text { scroll window which must be } \\
\text { scrolled to the bottom before } \\
\text { continuing }\end{array}$ & 17 & $19 \%$ \\
\hline $\begin{array}{l}\text { Terms appear on the screen as } \\
\text { a series of individual windows } \\
\text { that must be clicked }\end{array}$ & 21 & $23 \%$ \\
\hline $\begin{array}{l}\text { Click “I agree” at the end of a } \\
\text { form }\end{array}$ & 16 & $17 \%$ \\
\hline $\begin{array}{l}\text { Click "I agree" at the end of } \\
\text { each term }\end{array}$ & 45 & $49 \%$ \\
\hline $\begin{array}{l}\text { Terms are e-mailed to } \\
\text { purchaser after purchase }\end{array}$ & 12 & $13 \%$ \\
\hline $\begin{array}{l}\text { Terms are included with } \\
\text { product }\end{array}$ & 15 & $16 \%$ \\
\hline
\end{tabular}

* Respondents could select more than one response.

C. Summary. The picture that emerges is that purchasing over the internet is still not an everyday activity. When they do contract, respondents usually do so at night in their homes. Nevertheless, they do not take advantage of the relative abundance of time or lack of social pressure, especially for unexceptional transactions with well-known vendors. Beyond price and

33 See infra notes, and accompanying text. 
description of goods, few respondents generally read their e-standard forms. In fact, a large minority of respondents do not read their e-standard forms for the purchase of goods and services under any circumstances. ${ }^{34}$ But the common rhetoric that consumers never read their forms needs refinement. ${ }^{35}$ More than a third of the respondents read their e-forms when contracting with an unknown vendor and more than a third read when the value of the contract is high. An ample minority read their warranties and product information warnings. On the other hand, respondents rarely shop for advantageous terms.

Most respondents fail to read because they are in a hurry, while other significant but less frequently cited reasons for not reading include the belief that nothing will go wrong, that terms will be fair, and that competitors' terms will be comparable. The most effective method of increasing reading would be to require clicking "I agree" at the end of each term.

The question remains how should the law treat e-standard forms in light of this data. This issue is the subject of Part III.

${ }^{34}$ Some of the survey data reveal potentially interesting differences between purchasers and subscribers, between men and women, and between frequent and occasional purchasers. For example, as already reported, a majority of subscribers do not read their e-forms under any circumstances. See Table 3B. All four of the Table 3A respondents who generally read are men. Further, women respondents are more inclined to read based on the value of the item purchased (44\% men; 56\% women) and men based on the vendor (59\% men; $41 \%$ women). The percentage of non-readers is higher for occasional purchasers (once every six months or less) (63\%) than for frequent purchasers (once a month or more) (50\% ). However, because so few respondents read their standard forms, these results are not statistically significant according to the Fisher's Exact Test (2-sided). The lack of statistical significance, however, does not demonstrate the absence of a correlation between any of these groups and reading, it only means that the statistics do not prove there is a correlation.

If further research shows a correlation between frequency of purchase over the Internet and reading standard forms, the explanation may be that people who are not familiar with Internet purchasing are less likely to think about and protect their rights when they do use this unfamiliar contracting process.

35 See, e..g., Clayton P. Gillette, Rolling Contracts as an Agency Problem, 2004 Wis. L. Rev. 679, 680 ("buyers, or the vast majority of them, do not read the terms presented to them by sellers.”); see also Hillman \& Rachlinski, supra note , at 445-46. Professor Korobkin reports that "there appears to be little direct empirical data on this point. One court recently reported that AT\&T found that only 30 percent of its customers would read its entire form agreement updating contract terms, 10 percent would not read it at all, and 25 percent would throw away the mailing without even opening it. Ting v AT\&T, 182 F Supp 2d 902, 930 (ND Cal 2002).” See Russell Korobkin, Bounded Rationality, Standard Form Contracts, and Unconscionability, 70 U. CHI. L. REV. 1203, (2003). 
III. What Should the Law Do?

A. Is Market Pressure Enough? Standard forms are not a problem, of course, if a sufficient number of consumers read their forms and market pressure motivates businesses to draft fair, reasonable terms. If the survey is correct, new entrants into the e-marketplace and those selling high-price items should expect a substantial number of customers to read their forms, ${ }^{36}$ perhaps enough to discipline those businesses. ${ }^{37}$ Moreover, notwithstanding the apparent wide-scale failure of e-consumers to read standard forms of well-known vendors, to read terms governing average-priced transactions, and to read particular terms, such as dispute resolution and choice of forum, analysts have argued that a small number of readers in such contexts may be sufficient surrogates in competitive markets to discipline businesses. ${ }^{38}$ There is $^{3}$ therefore some reason to believe that a concern for reputation and lively competition for a market share should deter these e-businesses from drafting exploitive terms or even motivate them to write high-quality ones. ${ }^{39}$ In fact, the Internet may magnify this effect because of the relative ease in which consumers and watchdog groups can spread information about the nature of the terms. ${ }^{40}$ Further, e-businesses want to distinguish themselves from the multitude of disreputable

${ }^{36}$ See supra notes, and accompanying text.

37 See, e.g., Lee Goldman, My Way and the Highway: The Law and Economics of Chocie of Forum Clauses in Consumer Form Contracts, 86 N.W. U. L. Rev. 700, 719 (1992) ("Commentators . ... acknowledge that at least one-third of consumers must be informed to protect the remaining consumers’ interests.”).

38 Alan Schwartz \& Louis L. Wilde, Imperfect Information in Markets for Contract Terms: The Examples of Warranties and Security Interests, 69 Va. L. Rev. 1387 (1983).

39 This is the flip-side of the "lemons model" which posits that businesses will not produce better-than-average quality goods or terms if their customers refuse to pay a premium for the goods or terms because they do not know about them. "The lemons model applies quite straightforwardly to the case of form contracts since such contracts vary substantially in their terms and the drafting party . . . knows much more about those terms than the nondrafting party." Avery Katz, Standard Form Contracts, in 3 New Palgrave Dictionary of Economics and the Law 503 (1998) (discussing G. Akerlof, The Market for "Lemons": Quality Uncertainty and the Market Mechanism, 84 Quarterly Journal of Economics 488 (1970)). See also Margaret J. Radin, Humans, Computers, and Binding Commitment, 75 Ind. L. J. 1125, 1149 (1999). Businesses also may be able to spread the word about their advantageous terms through traditional advertising. See Gillette, supra note , at 697.

${ }^{40}$ Hillman \& Rachlinski, supra note, at 469-70. "If reputational concerns lead drafters of forms to moderate their opportunism, regulation may be largely unnecessary." Katz, supra note, at 505. 
firms that, because of ease of entry, populate the internet. ${ }^{41}$

But market pressure as a disciplining tool is problematic, especially with respect to wellknown businesses selling unexceptionally priced items. ${ }^{42}$ Such businesses in insufficiently competitive industries can afford to lose the few readers of their terms and therefore can ignore them, and those in competitive industries may be able to segregate readers and offer them special terms. $^{43}$ In fact, the new technology allows e-businesses to gather data on consumer behavior on the internet and offer special terms to anyone likely to read the standard form. As Rachlinski and I pointed out, “[c]areful segregation of consumers on the basis of their willingness to read and shop for terms would ensure that the small number of careful consumers would not discipline businesses as to the terms they offer to the rest of the consumers and would allow businesses to take advantage of the latter." 44

In addition, just as e-commerce offers consumers new tools, it arms businesses with novel and relatively inexpensive methods of manipulating consumers. For example, businesses can tinker with the style of presentation, including graphics and font sizes, can determine the effects of such manipulation of sites, and can utilize the most effective deterrent to reading. ${ }^{45}$ Businesses can also use techniques learned from advertising to influence purchasing decisions, including deflecting attention away from the terms. ${ }^{46}$

${ }^{41}$ Hillman \& Rachlinski, supra note , at 469.

42 Fly-by-night businesses that seek to defraud customers by disappearing after a creditcard payment do not care if the customer reads terms or not. The content of rules to police this type of behavior is beyond the scope of this article.

43 See, e.g., Gillette, supra note, at 695.

44 Hillman \& Rachlinski, supra note , at 472.

45 Id. at 482. "Studies of e-commerce confirm the suspicion that the Internet is not yet a consumer's paradise. In theory, the easy access to information that the Internet provides should reduce prices and reduce price dispersion between businesses that supply similar goods. Although e-commerce has had this effect on some commodities, wide dispersions in prices can be found in e-commerce. In some cases, the disparities are greater on the Internet than in the real world. These results indicate that e-consumers have yet to exploit the full benefits of the electronic environment. Despite the Internet's apparent benefits for consumers, these findings reveal that businesses still have many opportunities to exploit consumers' lack of information about goods and services.” Id. at 473.

46 See, e.g., See Jon D. Hanson \& Douglas A. Kysar, Taking Behavioralism Seriously: Some Evidence of Market Manipulation, 112 Harv. L. Rev. 1420, 1439-50 (1999). 


\section{B. What Should the Law Do?}

If market pressure cannot alone keep businesses in line, especially in everyday Internet transactions, what should the law do? The answer is nothing if the cost of intervention exceeds its benefits. Accordingly, before acting, a lawmaker should account for the costs and benefits of possible solutions and compare them with each other and against the status quo. The following discussion begins the analysis by setting forth an inventory of possible approaches and their potential costs and benefits.

Some of the suggestions that follow are designed to increase the numbers of readers of standard forms or, at least, to increase the opportunity to read, and, concomitantly, to decrease the instances of market failure. These suggestions also lend credence to autonomy reasons for enforcing e-standard forms. Consumers have an opportunity to read and to choose for themselves whether to contract. Standard-form transactions thus remain within the realm of contract, which itself serves the symbolic purpose of substantiating society's freedom. ${ }^{47}$ Relatedly, by ensuring an opportunity to read, the suggestions reinforce Llewellyn's conception of consumers' blanket assent to reasonable standard terms, so long as they have had a reasonable opportunity to read them. ${ }^{48}$ Blanket assent means that consumers have delegated to the drafter the duty of drafting boilerplate terms, just as they delegate to sellers the duty of selecting the component parts of the goods. ${ }^{49}$ Judicial policing of terms through doctrines such as unconscionability, reasonable expectations, and Section 211(3) of the Restatement (Second) of Contracts ensure that drafters do not overstep the reasonable bounds of their delegation. ${ }^{50}$

But measures that increase the opportunity to read may have a dark side. First, in reality, many or most e-consumers may still have ample rational reasons not to read (lack of bargaining power, commonality of terms within an industry) and cognitive shortcomings that impede reading (information overload). These suggestions therefore may fail to improve the situation very much. Even worse, by increasing the fairness of the process of contracting, the law may legitimize some terms that courts otherwise would be likely to strike on unconscionability or

47 See James J. White, Contracting Under Amended 2-207, 2004 Wis. L. Rev. 723

(2004). "Perhaps we would have a more just society if relations btween consumer and merchants appeared more honest, even if there is no change in consumer behavior or consumer transactions.” William C. Whitford, The Functions of Disclosure Regulation in Consumer Transactions, 1973 Wis. L. Rev. 400, 404, 439.

48 Hillman \& Rachlinski, supra note , at 454.

49 Jeffrey E. Thomas, An Interdisciplinary Critique of the Reasonable Expectations Doctrine, 5 Conn. Ins. L.J. 295, 307-08, n. 63 (1998).

${ }^{50}$ Hillman \& Rachlinski, supra note , at 456. See Brower v. Gateway 2000, Inc., 246 A.D.2d. 246 (1st Dep’t. 1998) (holding an arbitration provision unconscionable). 
other grounds. Rules creating a fair opportunity to read may thus may be a pyrrhic victory at best for the multitude that continue not to read. Two of the possible solutions discussed below therefore constitute different strategies for treating market failures, namely to provide a cooling off period or to enforce mandatory terms that govern in particularly problematic areas.

1. Continue the current legal direction. Numerous writers, including Rachlinski and I, have delineated the costs and benefits of standard forms and I will not repeat the discussion here. ${ }^{51}$ Suffice it to say that standard forms are here to stay because they reduce the drafter's cost of contracting by standardizing risks and eliminating bargaining costs. Further, drafters best can determine an efficient allocation of risk because of their expertise and experience. Drafters can pass along some of these savings to consumers. ${ }^{52}$

Current contract law, as applied to both the paper and e-worlds, recognizes the value of standard forms and also the potential for market failures. The current approach basically follows Llewellyn's conception of blanket assent, with contract law policing seller overreaching by striking unreasonable terms in presentation and content. ${ }^{53}$

To date, courts assessing on-line standard forms have paid special attention to the mode of presentation of terms. In a "browsewrap" contract, an e-consumer must "browse" through the website to find the optional hyperlink that would take her to the terms, so that she could find herself bound (according to the standard form) without ever seeing the terms. ${ }^{54}$ This presentation is common, ${ }^{55}$ although the judicial reaction has not been uniform. ${ }^{56}$ Some courts have held that browsewrap does not sufficiently call terms to the consumer's attention. ${ }^{57}$ On the other hand, courts uniformly have held enforceable "clickwrap" agreements because a party must click "I

51 See Hillman \& Rachlinski, supra note . For an interesting discussion, see Radin, supra note .

52 Gillette, supra note, at 698-703.

53 Hillman \& Rachlinski, supra note , at 454 .

54 See id. at 464.

55 See Kunz, et al., supra note, at 281.

56 See, e.g., Specht v. Netscape Communications Corp., 306 F.3d 17, 31 (2d Cir. 2002) ("[W]here consumers are urged to download free software at the immediate click of a button, a reference to the existence of license terms on a submerged screen is not sufficient to place consumers on inquiry or constructive notice of those terms.”). But see Register.com, Inc. v. Verio, Inc, 126 F. Supp. 2d 238 (S.D.N.Y. 2000).

57 Specht, 306 F. 3d at 30. 
agree" to the terms presented on the screen before completing the transaction..$^{58}$

The survey data reinforce what courts are doing if the goal is to ensure that consumers are aware of terms and to increase the possibility that they will read them. Recall that few respondents are likely to read under the browsewrap conception, whereas clickwrap presentations, especially those that require multiple clicking, appear to engender greater reading. ${ }^{59}$

It is possible that, as consumers increase their level of e-standard form contracting, their reading of terms also will increase.$^{60}$ Combined with the enforcement of clickwrap but not browsewrap, the current legal framework may be enough. On the other hand, the survey does not measure how poorer and less sophisticated consumers may conduct their e-transactions once the Internet reaches out to them. This may create a whole new set of issues beyond the scope of this paper.

2. Adopt more specific rules about what constitutes an agreement to terms. Contract law could adopt stricter standards for what constitutes an agreement to e-standard terms. For example, respondents indicated they would be more likely to read terms when they were required to click "I agree" at the end of each term. ${ }^{61}$ Contract law could adopt such an approach for online transactions. An intermediate approach would be to require clicking next to terms that consumers apparently do not generally read, such as forum selection and dispute resolution terms, especially since those terms have been controversial. ${ }^{62}$ Another approach would be to require bold or highlighted text for particular subject matter, which many respondents indicate

${ }^{58}$ See, e.g., Barnett v. Network Solutions, Inc., 38 S.W.3d 200, 204 (Tex. Ct. App. 2001) ("Parties to a written contract have the obligation to read what they sign; and, absent actual or constructive fraud ... they are not excused from the consequences attendant upon a failure to read the contract. The same rule applies to contracts which appear in an electronic format.”); Caspi v. Microsoft Network, 323 N.J.Super.118 (N.J. Super. Ct. App. Div. 1999). Of course, a court may find unenforceable a clickwrap term that is buried in fine print or incomprehensible. See Cem Kaner, Why You Should Oppose UCITA, 17 Computer Lawyer 20, 21 (2000).

59 See supra notes, and accompanying text.

${ }^{60}$ See supra note 34 (the percentage of non-readers is higher for occasonal purchasers than for frequent purchasers) .

${ }^{61}$ See supra notes, and accompanying text.

${ }^{62}$ Kunz, et. al., supra note , at 280-81. 
would increase their reading of terms. ${ }^{63}$ This strategy presupposes that consumers can find the terms in the first place, and therefore would be effective only if adopted in conjunction with one of the other forms of mandatory presentation of terms.

3. Require e-businesses to make terms available on-line on their websites. This suggestion would give prospective e-consumers even more time to contemplate and compare terms and would increase the legitimacy of the idea that e-consumers who have made a purchase have given their "blanket assent" to the terms. ${ }^{64}$ Currently, few businesses' terms are presented on their websites, at least in the software industry, ${ }^{65}$ but the effort should not be costly for businesses. ${ }^{66}$ Further, mandatory advance disclosure of terms is not foreign to the law and should not be too controversial. ${ }^{67}$

Although at least one commentator believes that advance disclosure of terms will increase shopping for terms, ${ }^{68}$ the survey results suggest otherwise. Recall that only $7 \%$ of those respondents who generally read at least some terms indicate that they shop for terms. ${ }^{69}$ Of course, if shopping for terms were easier, perhaps the percentage of shoppers would increase. On the other hand, some commentators doubt whether website coverage of terms prior to sales would increase readership at all. ${ }^{70}$ In addition, because businesses can easily change the appearance and content of their websites, mechanisms to ensure business compliance with

63 Certain warranty disclaimers must be conspicuous under Article 2 of the UCC. See, e.g., UCC Section 2-316.

64 Jean Braucher, Amended Article 2 and the Decision to Trust the Courts: The Case Against Enforcing Delayed Mass-Market Terms, Especially for Software, 2004 Wis. L. Rev. 753, 768 (2004) ("To force advance disclosure that facilitates shopping and thus market policing, courts should find no agreement to mass-market terms not publicly available before a customer initiates an order.”).

${ }^{65}$ Id. at 766-67 .

${ }^{66}$ Id. at 768 ("Advance disclosure in the age of computers and the Internet is simple and cheaper than printing copies and getting them into boxes.”).

67 See, e.g., Magnuson-Moss Warranty Act, 15 U.S.C. §2302(b)(1)(A) (2005).

68 Braucher, supra note, at 768.

69 See supra notes, and accompanying text.

${ }^{70}$ Gillette, supra note, at 687 ("It is unlikely that the Internet buyer will devote more time to reading text on the website than more traditional buyers devote to reviewing the terms of tangible [standard forms]"). Early studies of truth-in-lending legislation suggested that it did not improve reading and shopping for terms. Whitford, supra note , at 417-418. 
website disclosure and to prove the content of a website at the time of a purchase may be costly and ineffective.

The extent to which the availability of terms on websites improves reading and shopping will, of course, depend to some extent on how easily consumers can find the terms. Terms on a homepage or available by clicking a clearly labeled hyperlink may increase reading, but terms buried behind several pages and requiring several mouse clicks may not. ${ }^{71}$ Contract law could require the terms to be easily accessible from the homepage, but the precise language necessary to achieve this result may be difficult to promulgate without creating loopholes. ${ }^{72}$

Even if website disclosure does not increase consumer reading and shopping, it still might motivate businesses to write fair terms. Businesses may worry, for example, about exposure by watchdog groups that can monitor websites and spread the word about unreasonable terms electronically. ${ }^{73}$ However, the real concern for consumers is not outrageous terms that clearly would diminish a business's reputation and that courts likely would strike under current law, but marginal terms, such as those requiring reimbursement of attorneys' fees or arbitration in a nonneutral setting. And the benefits to businesses of writing and posting such terms may outweigh the costs of any adverse publicity.

If website disclosure does not discipline businesses, the strategy may backfire. All the terms-on-the-website proposal may do is to insulate businesses from claims of procedural unconscionability and thereby create a safe harbor for their creation of suspect terms. ${ }^{74}$

4. Cooling off period The survey reveals that e-consumers fail to read most often

${ }^{71}$ Gary M. Olson \& Judith S. Olson, Human-Computer Interraction: Psychological Aspects of the Human Use of Computing, 54 Annual Review of Psychology 491-516 (2003) ("There are design prescriptions gleaned from empirical studies of web-searching behavior that claim that if in three clicks users do not find information that at least suggests they are on the right track, they will leave the site.”) (available on the Web at http://arjournals.annualreviews.org/doi/abs/10.1146/annurev.psych.54.101601.145044?cookieSet $=1$ (last accessed on 3/9/05).

${ }^{72}$ See Robert A. Hillman, Internet Standard-Form Contracting-Would Website Disclosure of E-Terms Backfire? (draft).

73 See, e.g., Electronic Frontier Foundation, Dangerous Terms, http://www.eff.org/wp/eula.php, last accessed March 12, 2005.

${ }^{74}$ See Hillman, Internet Standard-Form Contracting, supra note . Website disclosure may nonetheless satisfy a "transitory, political demand for legislation benefitting consumers." Whitford, supra note , at 436. 
because they are in a hurry. ${ }^{75}$ However, the reason for their plight may be impatience, not real time constraints, because most contracting takes place in the home at night. ${ }^{76}$ The electronic age has created expectations of lightning speed and instant gratification and, not surprisingly, this atmosphere has spilled over to Internet contracting. ${ }^{77}$

Numerous state consumer protection laws prescribe a "cooling off” period after door to door sales, in which consumers can rescind their purchases because they fail to exercise restraint in that context too. ${ }^{78}$ Taking a lesson from these statutes, contract law could grant consumers the right, for a limited period of time, to rescind e-standard form transactions for a full refund.

There are significant problems with such a proposal, however. The lack of finality of transactions could make Internet contracting prohibitively expensive for e-businesses and for little gain. Consumers are as unlikely to read the terms after their purchase as before. ${ }^{79}$ In addition, in the case of goods, if the cooling off period extends beyond delivery, consumers are unlikely to find the time or make the effort to return them. ${ }^{80}$ On the other hand, all this means is that the consumer believes the net benefit of returning the goods is less than the net benefit of accommodating to the adverse terms. ${ }^{81}$

In fact, a prescribed cooling off period may backfire too. Many e-companies already offer 30 or 90 day return policies, but such policies may encourage consumers to forgo reading on the theory that they can always return the product later.

5. Adopt substantive mandatory rules for problematic terms, such as forum selection and choice of law. The results of the survey do not create confidence that in every-day transactions

75 See supra notes, and accompanying text.

76 See Gary M. Olson \& Judith S. Olson, Human-Computer Interraction: Psychological Aspects of the Human Use of Computing, 54 Annual Review of Psychology 491-516 (2003) (discussing impatience on the Internet) (available on the Web at http://arjournals.annualreviews.org/doi/abs/10.1146/annurev.psych.54.101601.145044?cookieSet $=1$ (last accessed on 3/9/05).

77 Hillman \& Rachlinski, supra note , at 479.

78 See, e.g. N.Y. Pers. Prop. §428 (McKinney 2005).

${ }^{79}$ See, e.g., Jean Braucher, The Failed promise of the UCITA Mass-Market concept and Its Lessons for Policing of Standard Form Contracts, 7 J. Small \& Emerging Bus. L. 393, 404 (2003); Korobkin, supra note , at 1265.

80 Braucher, supra note, at 768.

81 See White, supra note, at 748. 
many e-consumers will read and shop for terms, even if they are generally available and highlighted in some fashion. This is especially true of terms relating to breakdowns in performance, such as dispute resolution and forum selection clauses. Many of the rational and cognitive reasons for failing to read especially apply to such terms. Instead of attempting to create new incentives for consumers to read these terms, contract law could adopt rules delineating the limits of their acceptability. For example, Preliminary Draft I of the Principles of Software Contracts adopts the following rule with respect to choice of law:

The parties to a consumer contract may by agreement select the law of a state or foreign jurisdiction to govern their rights and duties with respect to an issue in contract if their transaction bears a reasonable relationship to the selected state or foreign jurisdiction. ${ }^{82}$

Substantive regulation of any kind, of course, runs into various objections, including freedom of contract, the fallibility of third-party regulation, and the costs of administration. In short, even if market failures pervade e-commerce, government regulation may constitute a net loss. ${ }^{83}$ For just one example, lawmakers must consider whether the lack of clarity of the term "reasonable relationship" in the choice of law provision above creates planning, drafting, and litigating costs that outweigh the benefits of the regulation.

\section{Conclusion}

Rachlinski and I wrote that the age of e-standard form contracting does not require a major overhaul of contract law. The results of the survey reported here do not necessitate a fundamental change of mind. But they do suggest the need for lawmakers to refine their approaches to take into account new opportunities for both businesses and consumers to enhance their positions in the e-world.

${ }^{82}$ Principles of the Law of Software Contracts, Preliminary Draft No. 1, American Law Institute (2004).

83 See, Goldman, supra note , at 721. 


\section{APPENDIX \\ SURVEY \\ CONTRACTS-ProfESSOR HILLMAN \\ QUESTIONNAIRE ON ELECTRONIC CONTRACTING ONLINE PURCHASES OF GOOD AND SERVICES:}

1. How frequently have you made an on-line purchase in the last year? [Select one.]
a. Every week.
b. Every two weeks.
c. Once a month.
d. Every two to three months.
e. Every six months.
f. Once a year.
g. Never.

2. Where do you usually make on-line purchases? [Select one.]
a. Home.
b. School/Work.
c. Cyber cafe.
d. Other. Please specify

3. When do you usually make on-line purchases? [Select one.]
a. Morning.
b. Afternoon.
c. Early evening.
d. Late at night.
e. No particular time.

4. As a general matter, other than price and description of the goods, do you read the electronic contract that governs your online purchases? [Select all that apply.]
a. Yes.
b. No.
c. Depends on the term.
d. Depends on the vendor.
e. Depends on the value of the item purchased.
f. Depends on other. Please specify

5. If you answered 4(c), which terms, other than price and product description, are you likely to read? [Select all that apply.]
a. Choice of forum/law agreement. 
b. Arbitration clause.

c. Product information disclosures/warnings.

d. Warranties/guarantees/return policy.

e. Other. Please specify

6. If you answered 4(d), which vendors' terms are you likely to read? [Select all that apply.]

a. Previously used vendor.

b. $\quad$ An online website of an existing brick and mortar vendor (e.g., www.barnesandnoble.com).

c. A well known online vendor (e.g., www.amazon.com/www.expedia.com).

d. An unknown vendor.

e. Other. Please specify

7. If you generally read at least some terms, do you usually shop around on the internet to find the most favorable terms? [Select one.]
a. Yes.
b. Yes, but only with respect to the price and/or description of the item purchased.
c. No.

8. If you fail to read the entire electronic contract, it is because: [Select all that apply.]

a. You would not understand the "legalese" anyway.

b. You believe that nothing will go wrong.

c. You believe the terms will be fair.

d. You are in a hurry.

e. You believe competitors' terms will be the same anyway.

f. You believe the law will protect you from egregious terms.

g. Other. Please specify

9. Which of the following terms, if unfavorable to you, are important enough to convince you not to make a purchase? [Select all that apply.]
a. Choice of forum/law agreement.
b. Arbitration clause.
c. Product information disclosures/warnings.
d. Warranties/guarantees/return policy.
e. Vendor's right to change terms.
f. Other. Please specify

10. You are more likely to read the terms of an online purchase: [Select all that apply.]

a. When you must click on a link to another page to read the terms.

b. When the terms appear in a pop-up window.

c. When the terms appear on the screen as bold or otherwise highlighted text. 
d. When the terms appear on the screen in a scroll window which must be scrolled to the bottom before continuing.

e. When the terms appear on the screen as a series of individual windows that must be clicked.

f. $\quad$ When you must click "I agree." at the end of the terms.

g. When you must click "I agree" at the end of each term.

h. When terms are e-mailed to you after the purchase.

i. When terms are included with the product.

j. $\quad$ When the online purchase is expensive.

k. I never will read the terms.

11. Do you expect to be legally bound by the terms of an online purchase? [Select one.]
a. Yes.
b. No.
c. Depends on the terms.

12. You believe you have formed a contract: [Select one.]
a. When you add an item to your shopping cart.
b. When you submit shipping and payment information.
c. When you click "I agree."
d. When you receive confirmation of an order.
e. When you receive the item.
f. When you open the item and inspect it.
g. When you begin using the item.

\section{ONLINE SUBSCRIPTIONS}

13. How many online services do you subscribe to (e.g. www.nytimes.com, www.slate.com, etc.)? [Select one.]
a. 0 .
b. 1-2.
c. 3-4.
d. 5 or more.

14. How many online services do you pay for (e.g., Everquest, Norton anti-virus updates, etc.)? [Select one.]
a. 0 .
b. 1-2.
c. 3-4.
d. 5 or more.

15. Where do you usually subscribe to online services? [Select one.] 

a. Home.
b. School/Work.
c. Cyber cafe.
d. Other. Please specify

16. When do you usually subscribe to online services? [Select one.]
a. Morning.
b. Afternoon.
c. Early evening.
d. Late at night.
e. No particular time.

17. As a general matter, other than price and description of the service, do you read the electronic service contract? [Select all that apply.]
a. Yes.
b. No.
c. Depends on the terms.
d. Depends on the vendor.
e. Depends on the service.
f. Depends on other. Please specify

18. If you answered 17(c), which terms do you read? [Select all that apply.]
a. Choice of forum/law agreement.
b. Arbitration clause.
c. Product information disclosures/warnings.
d. Warranties/guarantees.
e. Change of terms.
f. Cancellation of service.
g. Privacy agreement.
h. Other. Please specify

19. If you answered 17(d), which vendors' terms do you read? [Select all that apply.]
a. Previously used vendors.
b. An online website of an existing brick and mortar vendor (e.g., www.nytimes.com).
c. A well known online vendor (e.g., www.vault.com).
d. An unknown service.
e. Other. Please specify

20. If you generally read at least some terms, do you usually shop around on the internet to find the most favorable terms? [Select one.] 

a. Yes.
b. Yes, but only with respect to the price and/or description of the service.
c. No.

21. If you fail to read the entire electronic contract, it is because: [Select all that apply.]
a. You would not understand the "legalese" anyway.
b. You believe that nothing will go wrong.
c. You believe the terms will be fair.
d. You are in a hurry.
e. You believe competitors' terms will be the same anyway.
f. You believe the law will protect you from egregious terms.
g. Other. Please specify.

22. Which of the following terms, if unfavorable to you, are important enough to convince you not to subscribe? [Select all that apply.]
a. Privacy agreement.
b. Choice of forum/law agreement.
c. Arbitration clause.
d. Product information disclosures/warnings.
e. Warranties/guarantees.
f. Vendor's right to change terms.
g. Cancellation of service.
h. Other. Please specify.

23. You are likely to read the terms of an online subscription at initial sign-up: [Select all that apply.]
a. When you must click on a link to another page to read the terms.
b. When the terms appear in a pop-up window.
c. When the terms appear on the screen as bold or otherwise highlighted text.
d. When the terms appear on the screen in a scroll window which must be scrolled to the bottom before continuing.
e. When the terms appear on the screen as a series of individual windows that must be clicked.
f. $\quad$ When you must click "I agree." at the end of the terms.
g. When you must click "I agree." at the end of each term.
h. When terms are e-mailed to you after initial signup.
i. When the service is expensive.
j. I never read the terms.

24. Do you expect to be legally bound by the terms of a subscription? [Select one.]
a. Yes.
b. No.
c. Depends on the terms. 
25. You believe you have formed a contract for an online subscription: [Select one.]

a. When you submit payment information.

b. When you click "I agree."

c. When you receive confirmation of a subscription.

d. When you receive access.

e. When you begin using the service.

\section{GENERAL QUESTIONS:}

26. Gender:

a. Male.

b. Female.

27. Marital Status:

a. Single.

b. Married.

30. Age:
a. 20-30
b. $\quad 30-40$
c. 40-50
d. 50-60
e. Above 60 . 